\title{
Emisi Gas Rumah Kaca Sektor Pertanian di Kabupaten Tuban: Inventarisasi dan Potensi Aksi Mitigasi
}

\author{
Greenhouse Gas Emission on Agriculture Sectorin Tuban Regency: Inventory \\ and Potential Mitigation Action
}

\section{Dhina Mustikaningrum ${ }^{1}$}

Fakultas Pertanian, Universitas Sunan Bonang, Tuban, Indonesia

\section{Kristiawan Kristiawan}

Fakultas Pertanian, Universitas Sunan Bonang, Tuban, Indonesia

\author{
Suprayitno Suprayitno \\ Fakultas Pertanian, Universitas Sunan Bonang, Tuban, Indonesia
}

Artikel Masuk : 1 April 2021

Artikel Diterima : 28 Juni 2021

Tersedia Online : 31 Agustus 2021

\begin{abstract}
Abstrak: Pertanian menjadi salah satu sektor penyumbang emisi gas rumah kaca di Indonesia Kabupaten Tuban Provinsi Jawa Timur berpotensi besar menyumbangkan emisi gas rumah kaca di sektor pertanian mengingat luas lahan pertanian dan populasi ternak di daerah ini sangat tinggi. Penelitian ini bertujuan untuk melakukan inventarisasi emisi gas rumah kaca di sektor pertanian dan potensi aksi mitigasi di sektor yang sama. Hasil penelitian diharapkan dapat menjadi masukan bagi Pemerintah Kabupaten Tuban dalam merancang aksi mitigasi yang mudah diterapkan di lapangan. Metode yang digunakan untuk melakukan inventarisasi emisi gas rumah kaca ini adalah Tier-1 IPCC (Intergovernmental Panel on Climate Change) Tahun 2006, dimana faktor emisi yang digunakan adalah standard IPCC. Data aktivitas yang digunakan dalam inventarisasi emisi bersumber dari data sekunder. Sedangkan opsi mitigasi dihasilkan dari wawancara dengan perwakilan kelompok tani di Kabupaten Tuban. Hasil penelitian menunjukkan bahwa emisi Gas Rumah Kaca sektor pertanian di Kabupaten Tuban pada tahun 2019 mencapai 1.665,67 $\mathrm{Gg} \mathrm{CO}_{2}$-eq dengan rincian subsektor pertanian sebesar 1092,50 Gg CO 2 -eq dan subsektor peternakan sebesar 573,17 Gg CO2-eq. Pada subsektor pertanian, Kecamatan Plumpang menempati posisi teratas penyumbang emisi gas rumah kaca dan Kecamatan Tuban menempati posisi terendah. Sedangkan pada subsektor peternakan, Kecamatan Kerek menempati posisi teratas dalam berkontribusi terhadap emisi GRK dan terendah ada di Kecamatan Tuban. Melalui penerapan opsi mitigasi pemupukan berimbang dan penggunaan varietas padi rendah emisi, beban emisi GRK di Kabupaten Tuban dapat dikurangi hingga $156,43 \mathrm{Gg} \mathrm{CO}_{2}$-eq. Kedua opsi tersebut dipilih oleh petani karena lebih mudah dan murah tanpa bergantung pada pihak lain.
\end{abstract}

Kata Kunci: gas rumah kaca; mitigasi perubahan iklim; pertanian; peternakan

\footnotetext{
${ }^{1}$ Korespondensi Penulis: Fakultas Pertanian Universitas Sunan Bonang, Tuban, Indonesia

Email: dhina.mustikaningrum@gmail.com
} 


\begin{abstract}
The agricultural sector is one of the contributors to greenhouse gas emissions in Indonesia. The inventory of greenhouse gases in the agricultural sector is not only carried out on land management, but also in the livestock subsector. Tuban Regency, East Java Province has great potential to contribute to greenhouse gas emissions in the agricultural sector considering that the area of agricultural land and livestock population in this area is very high. This study aims to carry out an inventory of greenhouse gas emissions in the agricultural sector and potential mitigation actions in the same sector. The results of the research are expected to provide input for the Tuban Regency Government in designing mitigation actions that are feasible to implement. The greenhouse gas emission inventory is calculated using Tier-1 IPCC (International Panel on Climate Change) 2006 guidelines by multiplying activity data with emission factors according to IPCC standards. Activity data used for calculating GHG emission comes from secondary data. Meanwhile, the mitigation options obtained from interviews with representatives of farmer groups in Tuban Regency. The results show that the greenhouse gas emissions of the agricultural sector in Tuban Regency in 2019 is 1,665.67 Gg $\mathrm{CO} 2$-eq with details of the agricultural subsector of 1,092.50 $\mathrm{Gg} \mathrm{CO}_{2}$-eq and the livestock subsector of $573.17 \mathrm{Gg} \mathrm{CO}_{2}$-eq. In the agricultural subsector, Plumpang Subdistrict occupies the top position as a contributor to greenhouse gas emissions and Tuban Subdistrict is the lowest position. Meanwhile, in the livestock subsector, Kerek subdistrict occupies the top position in contributing to GHG emissions and the lowest is in Tuban subdistrict. Through the implementation of balanced fertilization mitigation options and the use of low-emission rice varieties, the GHG emission in Tuban Regency can be reduced by up to 156,43 Gg CO2-eq. Both options are selected by farmers because it is easier and cheaper without relying on others.
\end{abstract}

Keywords: agriculture; climate change; greenhouse gas; livestock; mitigation

\title{
Pendahuluan
}

Perubahan iklim adalah fenomena meningkatnya konsentrasi Gas Rumah Kaca (GRK) di atmosfer bumi. United Nations Framework Convention on Climate Change (UNFCC) menyebutkan bahwa terdapat enam jenis gas yang termasuk dalam kategori gas rumah kaca (GRK), yaitu: Karbon Dioksida $\left(\mathrm{CO}_{2}\right)$, Dinitro Oksida $\left(\mathrm{N}_{2} \mathrm{O}\right)$, Metana $\left(\mathrm{CH}_{4}\right)$, Sulfurheksaflorida $\left(\mathrm{SF}_{6}\right)$, Perflorokarbon (PFCS) dan Hidroflorokarbon (HFCs). Penyebab peningkatan konsentrasi gas tersebut berasal dari aktifitas manusia, seperti penggunaan bahan bakar fosil, perubahan tata guna lahan dan hutan, serta kegiatan pertanian dan peternakan. Indonesia mengalami dampak perubahan iklim tersebut, seperti peningkatan suhu, peningkatan muka air laut sampai bencana hidrometeorologi.

Pada Tahun 2011, Pemerintah Indonesia menerbitkan Peraturan Presiden Nomor 61 Tahun 2011 tentang Rencana Aksi Nasional Penurunan Emisi Gas Rumah Kaca untuk menunjukkan komitmennya bersama negara lainnya dalam mengurangi emisi gas rumah kaca. Melalui peraturan tersebut, Pemerintah Indonesia mendorong dilakukannya mitigasi perubahan iklim guna mengurangi pergerakan angka emisi di semua sektor, yaitu energi, industri, pertanian (termasuk peternakan), penggunaan lahan (termasuk kebakaran lahan gambut) dan sektor sampah. Di dalam peratutan tersebut disebutkan bahwa Pemerintah Kabupaten/Kota wajib menyusun Rencana Aksi Daerah Penurunan Emisi Gas Rumah Kaca. Kebijakan tersebut di atas diperkuat dengan Peraturan Gubernur Jawa Timur Nomor 27 tahun 2012 tentang Rencana Aksi Daerah Penurunan Emisi Gas Rumah Kaca Provinsi Jawa Timur. Dokumen tersebut dapat disusun dengan mempertimbangkan inventarisasi gas rumah kaca untuk kemudian dirumuskan rencana aksi sesuai dengan target pembangunan daerah.

Pertanian menjadi salah satu sektor penyumbang emisi gas rumah kaca di Indonesia. Pertanian berkontribusi terhadap emisi GRK sekitar 14\% pada skala global dan 7\% pada skala nasional (Ariani et al., 2015). Sektor pertanian tercatat menyumbang 10-12\% dari 
total gas rumah kaca antropogenik (akibat pengaruh aktivitas manusia), yang terdiri gas $\mathrm{N}_{2} \mathrm{O}$ dan $\mathrm{CH}_{4}$, Sedangkan sektor peternakan menyumbang sekitar $18 \%-51 \%$ gas rumah kaca antropogenik, yang sebagian besar terdiri dari gas $\mathrm{CH}_{4}$ (Goodland et al., 2009; Schils et al., 2007). Berdasarkan laporan Direktorat Jendral Perubahan Iklim Kementerian Lingkungan Hidup, sektor pertanian memberikan kontribusi terhadap emisi gas rumah kaca sebesar 96,305 Gg CO -eq atau 9,6 persen dari total emisi gas rumah kaca nasional tahun 2000 (Kementerian Lingkungan Hidup, 2012). Pada tahun 2012, emisi gas rumah kaca sektor pertanian meningkat menjadi $112,727 \mathrm{Gg} \mathrm{CO}_{2}$-eq atau 7,8 persen dari total emisi gas rumah kaca nasional. Artinya, emisi gas rumah kaca di Indonesia mengalami peningkatan di semua sektor.

Kabupaten Tuban merupakan salah satu Kabupaten di Jawa Timur yang berkontribusi pada emisi gas rumah kaca sekaligus merasakan dampak perubahan iklim. Penyebabnya adalah lokasi Kabupaten Tuban berada di Jalur Pantura yang padat kendaraan bermotor lintas provinsi, banyak industri besar, banyak usaha peternakan serta memiliki lahan pertanian dan kehutanan yang luas. Emisi di sektor transportasi bersumber dari pembakaran bahan bakar minyak oleh kendaraan, sehingga semakin padat kendaraan semakin besar emisi yang dihasilkan. Tuban memiliki jalan negara sepanjang 94,051 km yang merupakan jalur pantura, jalan provinsi sepanjang $81,760 \mathrm{~km}$ dan jalan kabupaten sepanjang 726,120 km (Pemerintah Kabupaten Tuban, 2016). Tercatat lebih dari 1.500 kendaraan roda dua dan roda empat atau lebih melewati jalur pantura Tuban setiap harinya, bahkan lebih dari 2.000 unit pada masa mudik (Rahayu, 2017). Hal inilah yang menyebabkan tingginya potensi emisi GRK sektor transportasi di Kabupaten Tuban.

Di sektor industri, Kabupaten Tuban juga memiliki potensi menyumbangkan emisi GRK yang tinggi. Terdapat dua pabrik semen skala nasional di Tuban, yaitu PT. Semen Indonesia dan PT. Solusi Bangun Indonesia (dulu PT. Holchim). Semen adalah sumber dari 8\% emisi karbondioksida $\left(\mathrm{CO}_{2}\right)$ di dunia (Lehne \& Preston, 2018). Kapastias produksi semen di PT. Semen Indonesia Tuban adalah 12 ton per tahun pada tahun 2017 (Wiangga, 2017) dan PT. Solusi Bangun Indonesia adalah sebesar 3,4 juta ton per tahun. Semen ini dihasilkan dari proses pembakaran bahan baku menjadi klinker dan proses ini menyebabkan terlepasnya karbondioksida ke atmosfer. Sehingga semakin tinggi produksi semen, maka semakin tinggi emisi yang dihasilkan. Penelitian terkait inventarisasi emisi di sektor industri semen menyebutkan bahwa kebutuhan panas untuk produksi semen adalah sebesar $1201,1098 \mathrm{kcal} / \mathrm{kg}$, dan dengan panas tersebut emisi gas karbondioksida yang dihasilkan adalah 6,178 ton $\mathrm{CO}_{2}$-eq (Mutiara \& Hadiyanto, 2013).

Di sektor peternakan, populasi ternak besar di Kabupaten Tuban pada tahun 2019 sebanyak 577.290 ekor dan unggas sebanyak 16.812.462 ekor (BPS Provinsi Jawa Timur, 2020). Khusus populasi jenis sapi perah, Kabupaten Tuban menempati posisi kedua terbanyak di Jawa Timur setelah Kabupaten Sumenep (BPS Kabupaten Tuban, 2021). Faktor emisi sapi perah untuk fermentasi enterik adalah yang tertinggi dibandingkan jenis ternak besar lainnya. Di sektor pertanian, lahan sawah irigasi di Kabupaten Tuban tercatat seluas $101.460 \mathrm{Ha}$ dan nonirigasi seluas 3.318 Ha yang tersebar di 20 kecamatan. Kabupaten Tuban juga merupakan salah satu sentra padi di Provinsi Jawa Timur dengan aktivitas pengelolaan sawah adalah penyumbang emisi gas rumah kaca.

Penelitian tentang dampak perubahan iklim di sektor pertanian menjelaskan bahwa banjir dan kekeringan menyebabkan tanaman mengalami puso serta meningkatnya salinitas tanah akibat kenaikan muka air laut (Surmaini et al., 2011). Penelitian serupa di Provinsi Bali juga mengungkapkan bahwa pergeseran musim kemarau dan musim penghujan akibat perubahan iklim menyebabkan penurunan luas lahan yang sesuai dengan agroklimat hingga 20\% selama tahun 1990-2009 (Sudarma \& As-syakur, 2018).

Di tengah kondisi tersebut, Kabupaten Tuban belum secara rutin melaporkan hasil inventarisasi emisi gas rumah kaca kepada pemerintah provinsi untuk dilaporkan kepada 
pemerintah pusat. Padahal dampak perubahan iklim telah dirasakan oleh masyarakat Tuban, diantaranya adalah kenaikan muka air laut dan peningkatan suhu harian. Jika sampai tahun 2050 tidak ada upaya mitigasi (Bussiness As Usual/BAU), maka kenaikan muka air laut di Tuban diprediksi meningkat hingga 1,43 meter dan suhu harian naik hingga $1,56{ }^{\circ} \mathrm{C}$ (Haristyana et al., 2012). Secara ekonomi, perubahan iklim ini juga mengakibatkan penurunan produksi petani tambak udang di Kabupaten Tuban. Penurunan produksi udang mencapai $25-50 \%$ dan biaya operasional adaptasi perubahan iklim naik 150-200\% yang berakibat pada menurunnya kesejahteraan petani tambak udang di Kabupaten Tuban (Suwarsih et al., 2019).

Semakin meluasnya dampak perubahan iklim mendorong dilakukannya mitigasi perubahan iklim di sektor pertanian. Namun penelitian-penelitian sebelumnya terkait mitigasi ini hanya fokus pada perhitungan penurunan emisi GRK yang dapat dilakukan berdasarkan skenario mitigasi, belum mengarah kepada jawaban apakah aksi mitigasi tersebut diterima dan dapat dilaksanakan oleh petani sebagai pelaku sekaligus pemilik lahan. Oleh karena itu, penelitian ini bertujuan untuk melakukan inventarisasi emisi gas rumah kaca di sektor pertanian dan potensi aksi mitigasi di sektor yang sama. Selain itu, penelitian ini juga memberikan opsi mitigasi yang layak diimplementasikan di lapangan berdasarkan rekomendasi dari petani. Adapun ruang lingkup sektor pertanian dalam hal ini meliputi budidaya tanaman unggulan yaitu padi baik yang ditanam di lahan irigasi maupun nonirigasi dan usaha peternakan di Kabupaten Tuban.

\section{Metode Penelitian}

\section{Perhitungan Emisi Gas Rumah Kaca (GRK)}

Estimasi emisi GRK di Kabupaten Tuban dihitung dengan menggunakan metode IPCC Guidelines tahun 2006 dengan pendekatan tier 1 (IPCC, 2006). Tier 1 merupakan pendekatan penghitungan emisi dengan menggunakan persamaan dasar dengan faktor emisi (emission factor/EF) yang digunakan sudah disediakan oleh IPCC (Interngovernmental Panel on Climate Change). IPCC adalah organisasi yang memberikan kebijakan berkaitan dengan perubahan iklim dengan tujuan memberikan sumber informasi objektif mengenai perubahan iklim. Perhitungan emisi gas rumah kaca yang dilakukan meliputi: (1) usaha ternak, dengan dilakukannya perhitungan emisi $\mathrm{CH}_{4}$ dari fermentasi enterik ternak besar (sapi potong, sapi perah, kerbau, kambing, domba, babi dan kuda) serta emisi $\mathrm{CH}_{4}$ dari pengelolaan kotoran ternak besar dan unggas (ayam kampung, ayam pedaging, ayam petelur, dan bebek/itik) dan emisi $\mathrm{N}_{2} \mathrm{O}$ langsung dan tidak langsung dari pengelolaan kotoran ternak, dan (2) budidaya tanaman padi, dengan dilakukannya perhitungan emisi $\mathrm{CH}_{4}$ dari budidaya padi, emisi $\mathrm{CO}_{2}$ dari penggunaan pupuk urea, serta emisi $\mathrm{N}_{2} \mathrm{O}$ langsung dan tidak langsung dari pengelolaan lahan. Perhitungan emisi GRK sektor pertanian pada penelitian ini dibatasi pada subsektor tanaman pangan unggulan Kabupaten Tuban, yaitu padi.

Seluruh gas yang dihasilkan baik dari sektor peternakan maupun pertanian dalam satuan gas $\mathrm{CH}_{4}, \mathrm{CO}_{2}$, dan $\mathrm{N}_{2} \mathrm{O}$, kemudian di konversi dalam $\mathrm{CO}_{2}$-ekuivalen dengan menggunakan nilai potensi pemanasan global atau global warming potential (GWP). Karbondioksida $\left(\mathrm{CO}_{2}\right)$ memiliki waktu tinggal di atmosfer paling lama di antara ketiga gas rumah kaca lainnya yaitu 5 hingga 2000 tahun. Meskipun demikian, $\mathrm{N}_{2} \mathrm{O}$ memiliki nilai potensi pemanasan global paling tinggi yaitu 298 kali potensi $\mathrm{CO}_{2}$, lebih tinggi dari potensi pemanasan global $\mathrm{CH}_{4}$ yaitu 25 kali potensi $\mathrm{CO}_{2}$ (Tabel 1). Jadi meskipun jumlah $\mathrm{N}_{2} \mathrm{O}$ yang teremisikan ke atmosfer lebih kecil daripada $\mathrm{CO}_{2}$, namun karena potensi pemanasan globalnya yang lebih besar maka akan menyebabkan efek pemanasan global yang lebih tinggi daripada $\mathrm{CO}_{2}$ atau $\mathrm{CH}_{4}$. 
Tabel 1. Potensi Pemanasan Global Gas Rumah Kaca

\begin{tabular}{crrr}
\hline Gas & $\begin{array}{c}\text { Waktu tinggal di atmosfer } \\
\text { (tahun) }\end{array}$ & Potensi Pemanasan Global (CO2-equivalen) \\
\hline $\mathrm{CO}_{2}$ & $5-2000$ & 1 \\
$\mathrm{CH}_{4}$ & 12 & 25 \\
$\mathrm{~N}_{2} \mathrm{O}$ & 144 & 298 \\
\hline
\end{tabular}

Sumber: IPCC, 2006; Lintangrino \& Boedisantoso, 2016

Data aktivitas yang digunakan pada perhitungan emisi gas rumah kaca Kabupaten Tuban adalah data sekunder dari Dinas Pertanian Kabupaten Tuban dan data dari BPS Kabupaten Tuban tahun 2021. Sedangkan data aktivitas yang tidak tersedia pada dua dokumen tersebut didapatkan melalui studi literatur dan wawancara kepada petani.

\section{Potensi Aksi Mitigasi}

Cara menghitung emisi gas rumah kaca setelah aksi mitigasi adalah dengan mengurangi emisi pada tahun 2019 (baseline) dengan angka emisi setelah aksi mitigasi diterapkan pada masing-masing sektor. Aksi mitigasi yang potensial diterapkan di Kabupaten Tuban didapatkan melalui studi dokumen yang dikembangkan oleh Badan Penelitian dan Pengembangan Pertanian, Kementerian Pertanian yang mengacu pada pedoman IPCC (Susilawati et al., 2020). Berdasarkan dokumen tersebut, petani akan memilih aksi mitigasi yang dapat diterapkan di wilayahnya dengan pertimbangan: biaya yang harus dikeluarkan, kemudahan dalam mengerjakan, dan peluang pendampingan dari pihak lain.

\section{Hasil dan Pembahasan}

\section{Data Aktivitas}

Data aktivitas merupakan bagian terpenting dalam melakukan inventarisasi gas rumah kaca. Data aktivitas sektor pertanian adalah satuan kegiatan manusia di bidang pertanian yang diperkirakan menimbulkan emisi GRK, seperti: jenis dan populasi ternak, pola pengelolaan kotoran ternak, luasan panen padi sawah, jenis irigasi, penggunaan pupuk urea, penggunaan pupuk $\mathrm{N}$, varietas padi yang digunakan dan lain sebagainya (Ariani et al., 2015). Sebagian besar data dapat diakses dari pelaporan Dinas Pertanian maupun Badan Pusat Statistik. Namun beberapa data seperti cara pengelolaan kotoran ternak, jumlah pupuk urea atau $\mathrm{N}$ dalam setahun baik pada lahan sawah maupun lahan kering, dan luas penggunaan varietas padi tertentu, umumnya didapatkan melalui survey langsung atau wawancara dengan petani.

Hasil penelusuran dokumen Kabupaten Tuban Dalam Angka 2020 didapatkan data aktivitas terkait subsektor peternakan dan subsektor pertanian (Tabel 2). Data aktivitas sektor pertanian di Kabupaten Tuban menunjukkan adanya klasterisasi. Kecamatan yang berada di sekitar aliran sungai Bengawan Solo seperti Widang, Plumpang, Rengel dan Soko didominasi lahan pertanian khususnya sawah irigasi yang luas. Sedangkan klaster tengah seperti Merakurak, Kerek, Semanding dan Montong didominasi aktivitas peternakan dengan populasi yang cukup tinggi.

\section{Subsektor Pertanian}

Pada sektor pertanian data aktivitas yang digunakan adalah data sekunder berupa luas lahan sawah irigasi dan nonirigasi di Kabupaten Tuban pada tahun 2019. Sedangkan data aktivitas berupa sistem pengelolaan lahan dan dosis pupuk didapatkan dari 
wawancara dengan petani. Sumber emisi di sektor pertanian bersumber dari emisi $\mathrm{CH}_{4}$ dari budidaya padi, emisi $\mathrm{CO}_{2}$ dari penggunaan pupuk urea, serta emisi $\mathrm{N}_{2} \mathrm{O}$ langsung dan tidak langsung dari pengelolaan lahan sawah. Emisi gas $\mathrm{CH}_{4}$ dari pengelolaan sawah dihasilkan dari proses dekomposisi bahan organik secara anaerob. Emisi $\mathrm{CH}_{4}$ dari pengelolaan sawah dipengaruhi oleh rejim pengairan, jenis tanah, varietas padi, dan penggunaan bahan organik sebelum dan selama masa tanam.

Tabel 2. Data Aktivitas Subsektor Pertanian dan Peternakan

\begin{tabular}{llrrrrrrrr}
\hline & & \multicolumn{7}{c}{$\begin{array}{c}\text { Luas Panen Lahan } \\
\text { Pertanian (Ha) }\end{array}$} & \multicolumn{7}{c}{ Populasi Ternak (Ekor) } \\
\cline { 2 - 9 } No & Kecamatan & $\begin{array}{c}\text { Sawah } \\
\text { Irigasi }\end{array}$ & $\begin{array}{c}\text { Sawah } \\
\text { Non } \\
\text { Irigasi }\end{array}$ & $\begin{array}{c}\text { Sapi } \\
\text { Potong }\end{array}$ & $\begin{array}{c}\text { Sapi } \\
\text { Perah }\end{array}$ & Kerbau & Kambing & Domba & Kuda \\
\hline 1 & Kenduruan & 2.189 & 8 & 15.269 & 0 & 32 & 1.673 & 790 & 0 \\
2 & Bangilan & 4.434 & 60 & 13.259 & 0 & 389 & 5.853 & 6.273 & 2 \\
3 & Senori & 4.712 & 128 & 13.006 & 0 & 0 & 3.377 & 4.996 & 1 \\
4 & Singgahan & 6.733 & 115 & 8.554 & 0 & 0 & 5.025 & 2.844 & 0 \\
5 & Montong & 3.310 & 0 & 25.687 & 0 & 0 & 9.291 & 6.504 & 0 \\
6 & Parengan & 4.344 & 435 & 19.276 & 0 & 0 & 5.144 & 4.647 & 0 \\
7 & Soko & 10.598 & 10 & 21.024 & 0 & 0 & 10.673 & 8.887 & 14 \\
8 & Rengel & 5.621 & 959 & 10.418 & 0 & 0 & 5.098 & 4.526 & 8 \\
9 & Grabagan & 1.079 & 1 & 14.168 & 0 & 0 & 4.019 & 1.611 & 0 \\
10 & Plumpang & 12.546 & 162 & 9.919 & 0 & 0 & 4.335 & 4.239 & 0 \\
11 & Widang & 12.661 & 0 & 5.264 & 0 & 0 & 6.189 & 4.922 & 1 \\
12 & Palang & 4.146 & 702 & 16.188 & 0 & 0 & 5.931 & 2.848 & 8 \\
13 & Semanding & 1.862 & 7 & 27.731 & 11 & 0 & 13.081 & 1.974 & 27 \\
14 & Tuban & 1.086 & 0 & 5.116 & 39 & 0 & 6.170 & 1.830 & 0 \\
15 & Jenu & 3.841 & 0 & 18.286 & 0 & 0 & 9.970 & 7.282 & 0 \\
16 & Merakurak & 6.166 & 60 & 26.406 & 0 & 0 & 9.839 & 8.159 & 0 \\
17 & Kerek & 2.462 & 0 & 28.114 & 0 & 16 & 13.589 & 4.407 & 1 \\
18 & Tambakboyo & 4.674 & 0 & 19.767 & 0 & 0 & 9.574 & 5.835 & 1 \\
19 & Jatirogo & 3.558 & 451 & 20.319 & 0 & 191 & 2.959 & 3.559 & 0 \\
20 & Bancar & 5.438 & 220 & 26.432 & 0 & 0 & 6.715 & 7.708 & 0 \\
\hline
\end{tabular}

Sumber: BPS Kabupaten Tuban, 2021

Emisi $\mathrm{N}_{2} \mathrm{O}$ tidak langsung dan tidak langsung dari pengelolaan tanah berasal dari aplikasi pupuk N, baik organik maupun anorganik. Data aktivitas yang digunakan pada perhitungan emisi $\mathrm{N}_{2} \mathrm{O}$ langsung ini adalah data lahan sawah basah dan kering karena pengaruh kondisi aerob dan anerob. Selain menghasilkan emisi $\mathrm{N}_{2} \mathrm{O}$ langsung, pemberian pupuk $\mathrm{N}$ dalam tanah juga menghasilkan emisi $\mathrm{N}_{2} \mathrm{O}$ tidak langsung dari volatilisasi $\mathrm{NH}_{3}$ dan $\mathrm{NO}_{\mathrm{x}}$ dari tanah. Gas tersebut menghasilkan nitrat dan nitrit yang diendapkan kembali ke dalam tanah dan air (IPCC, 2006). Pendekatan perhitungan emisi $\mathrm{N}_{2} \mathrm{O}$ tidak langsung dari tanah yang dikelola didasarkan pada fraksi deposisi nitrogen yang tervolatilisasi, sehingga tidak perlu membedakan penggunaannya pada lahan basah maupun lahan kering (Purnamasari et al., 2020).

Hasil perhitungan menunjukkan bahwa total emisi GRK subsektor Pertanian di Kabupaten Tuban mencapai 1.092,50 Gg CO -eq (Tabel 3). Emisi tertinggi bersumber dari emisi $\mathrm{CH}_{4}$ dari budidaya padi yaitu sebesar $675,17 \mathrm{Gg} \mathrm{CO}_{2}$-eq atau 62 persen dari total emisi di sektor pertanian. Sedangkan emisi GRK terendah disumbangkan oleh emisi $\mathrm{N}_{2} \mathrm{O}$ tidak langsung dari pengelolaan lahan sawah, yaitu sebesar $14,14 \mathrm{Gg} \mathrm{CO}_{2}$-eq. Luas lahan 
sawah irigasi sebagai penyumbang emisi $\mathrm{CH}_{4}$ dari budidaya padi di Kabupaten Tuban mencapai $101.460 \mathrm{Ha}$.

Persentase sebaran emisi berdasarkan sumbernya ini sedikit berbeda dengan temuan sebelumnya di Kabupaten Boyolali bahwa emisi $\mathrm{CH}_{4}$ dari pengolahan sawah mencapai $53,64 \%$ dan emisi $\mathrm{N}_{2} \mathrm{O}$ langsung dari pengelolaan lahan sawah sebesar 30,47\% (Purnamasari et al., 2020). Perbedaan angka tersebut dikarenakan adanya input data aktivitas berupa aplikasi pupuk kandang sebesar 2 ton/hektar. Dalam perhitungan emisi GRK menggunakan Metode Tier-1 IPCC (2006), penggunaan pupuk kandang mempengaruhi nilai emisi di subsektor peternakan maupun pertanian. Di Kabupaten Tuban, belum tersedia informasi baik dari Dinas Pertanian Ketahanan Pangan maupun dari kelompok tani terkait dengan data aktivitas ini.

Tabel 3. Perhitungan Emisi Subsektor Pertanian Berdasarkan Sumbernya

\begin{tabular}{|c|c|c|c|}
\hline No & Sumber Emisi Subsektor Pertanian & $\begin{array}{l}\text { Total Emisi } \\
\left(\mathrm{Gg} \mathrm{CO}_{2} \text {-eq) }\right.\end{array}$ & $\begin{array}{l}\text { Persentase } \\
(\%)\end{array}$ \\
\hline 1 & Emisi $\mathrm{CH}_{4}$ dari Pengolahan Sawah & 675,17 & 62 \\
\hline 2 & Emisi $\mathrm{CO}_{2}$ dari penggunaan pupuk urea & 23,05 & 2 \\
\hline 3 & Emisi $\mathrm{N}_{2} \mathrm{O}$ langsung dari pengelolaan lahan sawah & 380,14 & 35 \\
\hline 4 & $\begin{array}{l}\text { Emisi } \mathrm{N}_{2} \mathrm{O} \text { tidak langsung dari pengelolaan lahan } \\
\text { sawah }\end{array}$ & 14,14 & 1 \\
\hline Total & & $1.108,79$ & 100 \\
\hline
\end{tabular}

Tanah sawah adalah kondisi ideal bagi terbentuknya gas metana $\left(\mathrm{CH}_{4}\right)$, karena praktek bercocok tanam padi umumnya dilakukan penggenangan sepanjang produksi. Kondisi anaerob ini menguntungkan bakteri metanogen untuk melakukan dekomposisi bahan organik menghasilkan gas metana atau disebut sebagai proses metanogenesis (Johnson et al., 2007). Produksi gas metana $\left(\mathrm{CH}_{4}\right)$ dari lahan sawah lebih tinggi dibandingkan gas lainnya. Potensial produksi gas metana berkisar antara 3,21 sampai $112,30 \mathrm{mg} \mathrm{CH}$ per kilogram tanah (Setyanto et al., 2002). Hal ini sejalan dengan hasil penelitian ini yang menempatkan emisi $\mathrm{CH}_{4}$ dari pengolahan sawah sebagai kontributor tertinggi bagi emisi GRK di subsektor pertanian dengan 61 persen dari total emisi.

Berdasarkan sebaran lokasi, emisi GRK di sektor pertanian tertinggi dihasilkan Kecamatan Plumpang dengan total emisi mencapai 98,95 $\mathrm{Gg} \mathrm{CO}_{2}$-eq, sedikit lebih tinggi daripada Kecamatan Soko dengan total emisi 96,32 Gg $\mathrm{CO}_{2}$-eq dan Kecamatan Widang dengan total emisi $95,72 \mathrm{Gg} \mathrm{CO}$-eq (Gambar 1). Emisi GRK terendah dihasilkan Kecamatan Tuban dengan total emisi mencapai 13,03 $\mathrm{Gg} \mathrm{CO}_{2}$-eq. Sebagai kawasan perkotaan, Kecamatan Tuban hanya memiliki lahan sawah seluas 1.086 Ha sebagai salah satu sumber dihasilkannya emisi. Berbeda halnya dengan Kecamatan Plumpang yang memiliki luas lahan sawah irigasi mencapai $12.546 \mathrm{Ha}$ dan nonirigasi $162 \mathrm{Ha}$, sehingga kontribusi terhadap emisi GRK di Kecamatan ini sangat tinggi. Kecamatan Widang memiliki luas lahan sawah irigasi $12.661 \mathrm{Ha}$, lebih tinggi dibandingkan Kecamatan Soko dengan luas sawah irigasi 10.598 Ha. Namun Kecamatan Soko memiliki lahan sawah nonirigasi sedangkan Kecamatan Widang tidak memiliki sawah nonirigasi.

Kecamatan Soko, Rengel, Plumpang dan Widang adalah empat kecamatan yang berbatasan dengan sungai besar Bengawan Solo. Aktivitas pertanian khususnya irigasi sangat mengandalkan air sungai Bengawan Solo sebagai sumber air baku. Pemenuhan kebutuhan air irigasi cukup melimpah mengingat potensi air sungai Bengawan Solo di Kabupaten Tuban mencapai 815 juta $\mathrm{m}^{3}$ /tahun (Kementerian Pekerjaan Umum, 2010). Kondisi ini memungkinkan tersedianya air irigasi sepanjang tahun. Sehingga, produksi gas metana, dinitrooksida dan karbondioksida dapat terjadi sepanjang tahun, Hal ini tampak 
dari sebaran kecamatan di Kabupaten Tuban yang menyumbangkan emisi GRK yang sangat tinggi berada di wilayah yang berbatasan langsung dengan Bengawan Solo (Gambar 2). Penyusunan klasifikasi ini didasarkan pada distribusi nilai emisi GRK di tiap Kecamatan.

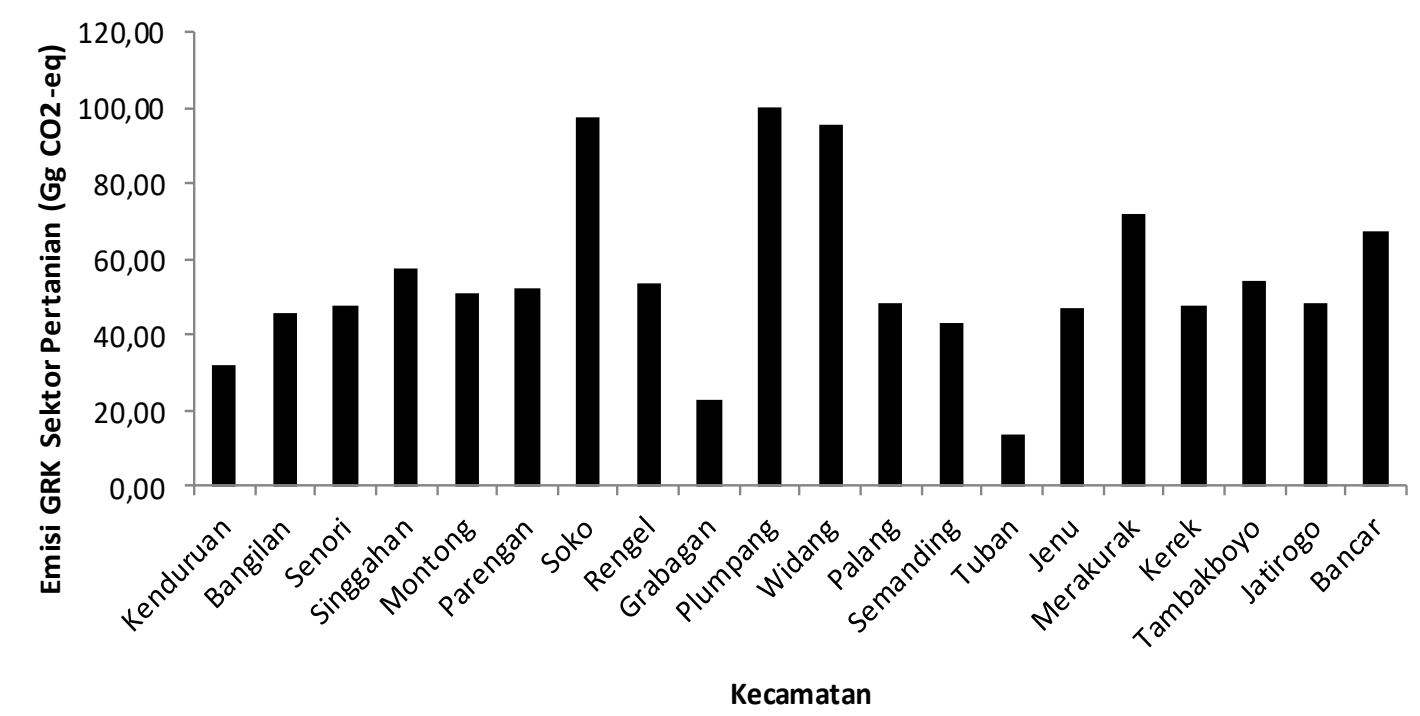

Gambar 1. Sebaran Emisi Gas Rumah Kaca Subsektor Pertanian di Kabupaten Tuban

Selain menghasilkan gas metana $\left(\mathrm{CH}_{4}\right)$ akibat proses penggenangan, lahan sawah juga berpotensi menghasilkan gas dinitrogen oksida $\left(\mathrm{N}_{2} \mathrm{O}\right)$ yang cukup tinggi. $\mathrm{N}_{2} \mathrm{O}$ secara alami dapat dihasilkan dari proses denitrifikasi dan nitrifikasi bahan organik. Memutus proses penggenangan dengan irigasi terputus mampu menurunkan potensi pemanasan global sebesar 34,9\% (Utaminingsih \& Hidayah, 2012). Hasil penelitian lainnya juga menunjukkan bahwa penggunaan pupuk NPK dapat meningkatkan emisi $\mathrm{CH}_{4}$, sedangkan penerapan intermittent irrigation menurunkan $60 \%$ emisi $\mathrm{CH}_{4}$ dibandingkan dengan pengairan tergenang (Kartikawati \& Nursyamsi, 2013). Pengelolaan kotoran ternak dan penambahan pupuk nitrogen pada tanah juga akan mengalami proses nitrifikasi dan denitrifikasi sehingga berdampak terhadap produksi gas $\mathrm{N}_{2} \mathrm{O}$ dari pengolahan tanah. Terbukti bahwa penambahan pupuk NPK mampu meningkatkan produksi gas $\mathrm{N}_{2} \mathrm{O}$ hingga 7\% dibandingkan tanpa pemupukan (Kartikawati \& Nursyamsi, 2013). Oleh karena itu, lahan-lahan dengan irigasi terus menerus yang banyak dijumpai di Kecamatan Soko, Rengel, Plumpang dan Widang berkontribusi tinggi dalam menghasilkan emisi gas rumah kaca di subsektor pertanian.

Guna menurunkan emisi GRK pada praktek budidaya padi, telah dikaji varietasvarietas padi rendah emisi dan tahan terhadap irigasi intermiten atau irigasi berselang. Irigasi berselang ini merupakan pengaturan kondisi lahan dalam kondisi kering dan tergenang secara bergantian. Hasil penelitian sebelumnya menyebutkan bahwa padi yang menghasilkan emisi metana rendah memiliki karakteristik penciri biomassa sedikit, luas rongga aerenkima akar sempit dan ketegaran morfologi batang dan daun lemah di antaranya adalah varietas Inpari 13 dan Mekongga (Arisandi et al., 2018). Varietas Mekongga juga terbukti rendah emisi dan memiliki produksi yang tinggi sehingga direkomendasikan untuk ditanam sebagai upaya adaptasi maupun mitigasi perubahan iklim (Kartikawati et al., 2018). 


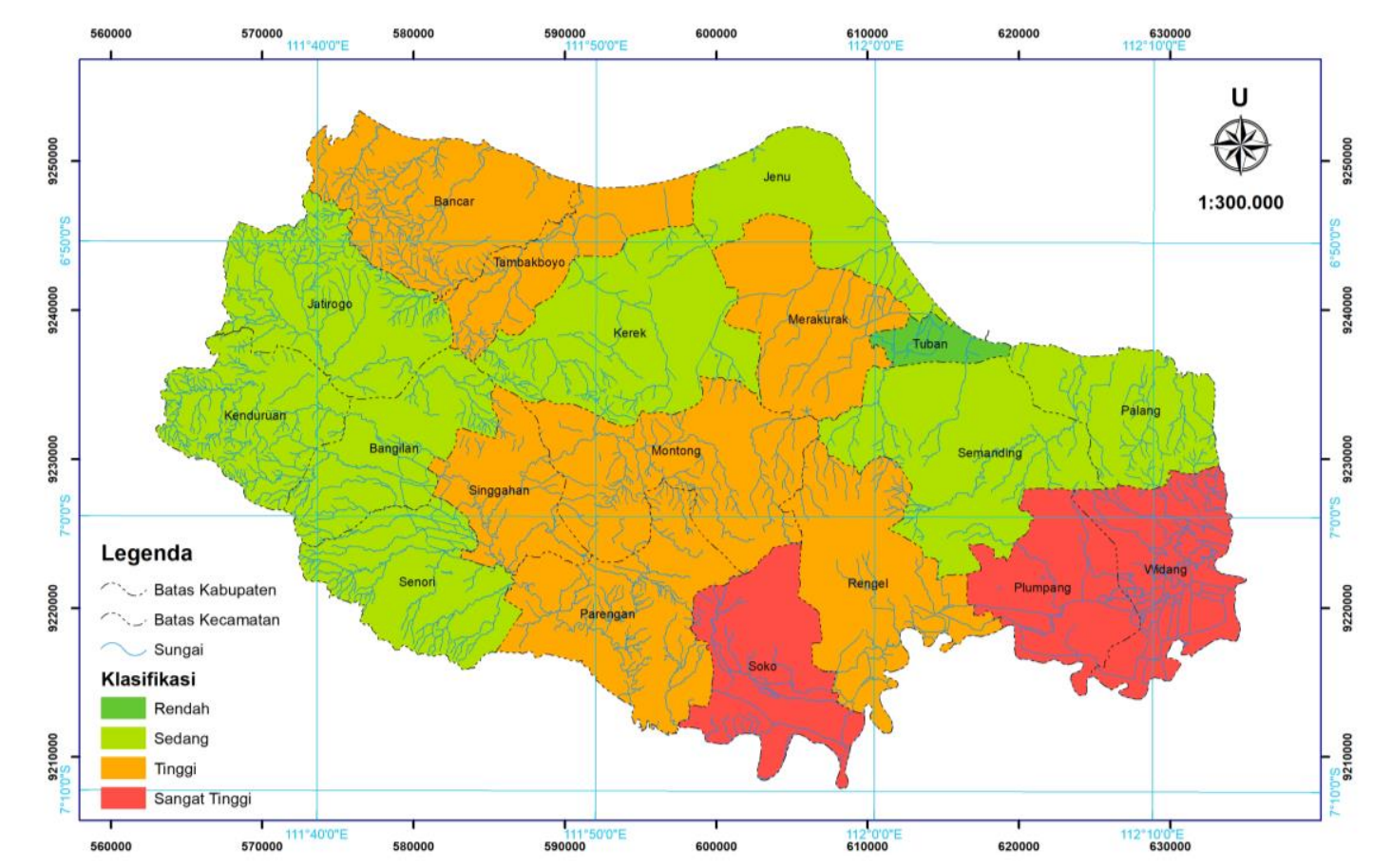

Gambar 2. Sebaran Emisi Gas Rumah Kaca Subsektor Pertanian di Kabupaten Tuban

\section{Subsektor Peternakan}

Data aktivitas yang digunakan pada subsektor peternakan adalah data sekunder berupa populasi ternak, baik ternak besar maupun unggas di Kabupaten Tuban pada tahun 2019. Data tersebut didapatkan dari Badan Pusat Statistik yang diakses dari dokumen Kabupaten Tuban Dalam Angka 2020. Data berat rata-rata ternak dan sistem pengelolaan kotoran didapatkan dari hasil wawancara. Hasil wawancara menunjukkan bahwa pengelolaan kotoran dari ternak sapi dikelola dengan cara ditumpuk sampai kering/Dry Lot. Demikian juga dengan jenis ternak lainnya. Pengelolaan Kotoran kambing, kuda maupun babi juga 100\% dikelola dengan cara ditumpuk hingga kering/Dry Lot. Kotoran unggas jenis ayam pedaging dan ayam petelur umumnya ditumpuk di kandang, sedangkan ayam kampung dan bebek tersebar di luar kandang. Faktor emisi yang digunakan untuk sektor peternakan ini menggunakan pedoman IPCC Guidelines tahun 2006.

Sumber emisi di sektor peternakan terdiri dari Emisi $\mathrm{CH}_{4}$ Fermentasi Enterik, Emisi $\mathrm{CH}_{4}$ Pengelolaan Kotoran Ternak, Emisi $\mathrm{N}_{2} \mathrm{O}$ langsung dari Pengelolaan Kotoran Ternak dan Emisi $\mathrm{N}_{2} \mathrm{O}$ tidak langsung dari Pengelolaan Kotoran Ternak. Hasil perhitungan menunjukkan bahwa total emisi gas rumah kaca di sektor peternakan di Kabupaten Tuban adalah sebesar 573,17 Gg CO 2 -e (Tabel 4). Dari total angka tersebut, angka emisi terbesar diperoleh dari fermentasi enterik yaitu sebesar 434,45 $\mathrm{Gg} \mathrm{CO}_{2}$-e atau 76 persen dari total emisi di sektor peternakan. Fermentasi enterik merupakan bagian alami dari proses pencernaan pakan oleh mikroba rumen pada ternak jenis ruminansia seperti sapi, kambing, domba, kerbau, kuda dan babi. Proses fermentasi ini menghasilkan rantai karbon dan hidrogen yang digunakan ternak sebagai sumber energi atau digunakan oleh bakteri metanogen untuk menghasilkan gas metana $\left(\mathrm{CH}_{4}\right)$.

Tingginya emisi yang bersumber dari fermentasi enterik disebabkan karena populasi ternak jenis ruminansia yang tinggi, khususnya sapi potong. Hasil penelitian terkait emisi di sektor peternakan menunjukkan bahwa populasi sapi potong berbanding lurus dengan jumlah emisi $\mathrm{CH}_{4}$ dan $\mathrm{N}_{2} \mathrm{O}$ yang dihasilkan (Munawaroh \& Widiawati, 2017) Sapi potong 
juga merupakan kontributor emisi tertinggi di sektor peternakan dibandingkan jenis ternak lainnya, yaitu 38,49\% (Nurhayati \& Widiawati, 2017). Jumlah ternak sapi potong di Kabupaten Tuban cukup tinggi yaitu 344.203 ekor yang tersebar di 20 kecamatan. Meskipun faktor emisi sapi perah (61 $\mathrm{kg} \mathrm{CH}_{4}$ /ekor) lebih tinggi dibandingkan sapi potong (47 $\mathrm{kg} \mathrm{CH}_{4}$ /ekor), namun karena populasi sapi potong lebih tinggi, maka emisi dari ternak potong juga lebih tinggi.

Tabel 4. Perhitungan Emisi Subsektor Peternakan Berdasarkan Sumbernya

\begin{tabular}{clrr}
\hline \multirow{2}{*}{ No } & \multicolumn{1}{c}{ Sumber Emisi Subsektor Peternakan } & $\begin{array}{c}\text { Total Emisi } \\
\left(\mathbf{G g ~ C O}_{2} \text {-eq) }\right.\end{array}$ & $\begin{array}{c}\text { Persentase } \\
(\boldsymbol{\%})\end{array}$ \\
\hline 1 & Emisi $\mathrm{CH}_{4}$ Fermentasi Enterik & 434,45 & 76 \\
2 & Emisi $\mathrm{CH}_{4}$ Pengelolaan Kotoran Ternak & 11,40 & 2 \\
3 & Emisi $\mathrm{N}_{2} \mathrm{O}$ langsung dari Pengelolaan Kotoran & 110,66 & 19 \\
& Ternak & & \\
4 & Emisi $\mathrm{N}_{2} \mathrm{O}$ tidak langsung dari Pengelolaan & 16,66 & 3 \\
& Kotoran Ternak & & 100 \\
\hline Total & & 573,17 & \\
\hline
\end{tabular}

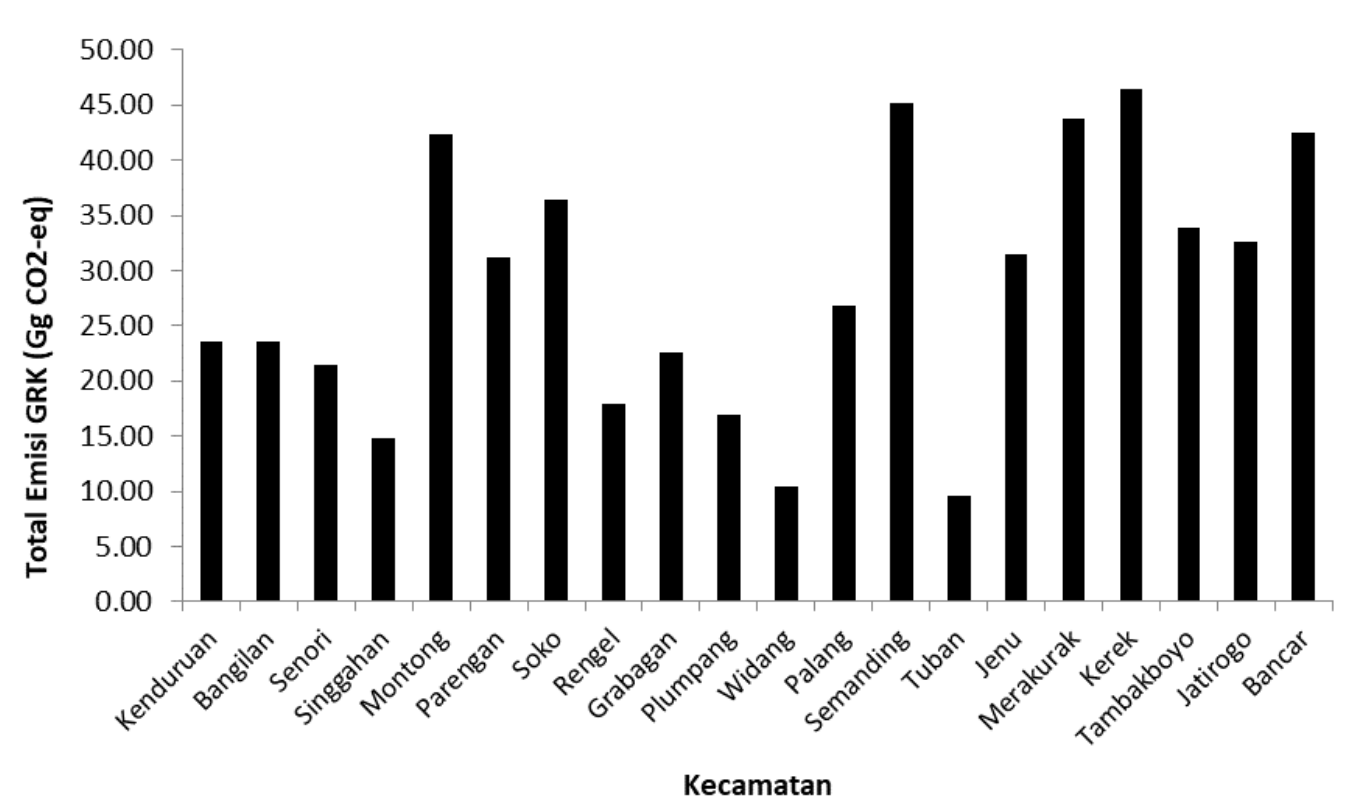

Gambar 3. Estimasi Emisi Gas Rumah Subsektor Peternakan di Kabupaten Tuban

Dilihat dari sebaran emisi, Kecamatan Kerek menempati posisi teratas dalam berkontribusi terhadap emisi GRK sektor peternakan di Kabupaten Tuban dengan total 46,40 Gg CO -eq (Gambar 3). Sedangkan total emisi GRK terendah ada di Kecamatan Tuban dengan jumlah 9,61 Gg CO 2 -eq. Hal ini disebabkan karena angka populasi ternak besar di Kecamatan Kerek adalah yang tertinggi di Kabupaten Tuban, khususnya sapi potong sebanyak 28.114 ekor dan kambing 13.589 ekor. Keduanya menyumbang angka emisi GRK tinggi dari sumber fermentasi enterik dan pengelolaan kotoran ternak.

Fermentasi enterik dihasilkan dari proses pencernaan karbohidrat dalam pakan ternak hewan jenis ruminansia seperti sapi, kambing, kerbau dan domba. Proses ini mengkonversi nutrisi pakan ternak menjadi gas metana $\left(\mathrm{CH}_{4}\right)$ di dalam rumen (perut). Selain menghasilkan metana dari fermentasi enterik, feses ternak jenis ruminansia juga 
merupakan bahan organik yang mengandung bakteri. Proses dekomposisi feses ini menghasilkan gas $\mathrm{CH}_{4}$ yang merupakan sumber emisi gas rumah kaca. Oleh karena itu, kualitas pakan ternak sangat mempengaruhi produksi gas metana baik oleh proses fermentasi enterik maupun pengelolaan kotoran (feses). Peternak di Kabupaten Tuban umumnya memberikan jerami padi dan rumput gajah sebagai pakan ternak. Jerami padi dan kombinasi jerami padi dengan rumput gajah terbukti mampu menghasilkan gas metan lebih tinggi dibandingkan rumput sajah saja (Puspitasari et al., 2015). Karena kebiasaan dalam mengelola ternak relatif sama, maka perbedaan nilai emisi di subsektor peternakan di Kabupaten Tuban disebabkan oleh populasi ternak di tiap kecamatan (Gambar 4).

Pengelolaan pakan ternak merupakan alah satu upaya penurunan emisi gas rumah kaca yang mengintegrasikan pertanian dan peternakan. Penggunaan limbah biomassa (sisa panen), salah satunya adalah jerami. Jerami dapat dimanfaatkan sebagai hijauan pakan ternak ketika musim kemarau tiba dengan cara dikomposkan meskipun kualitasnya rendah. Namun penelitian terdahulu mengungkapkan bahwa melalui penambahan pakan tambahan seperti silase, jerami amoniasi dan penggunaan Urea Molasse Multinutrient Block mampu menekan emisi $\mathrm{CO}_{2}$ hingga 19\% (Pramono, 2016). Sistem integrasi tanaman-ternak di wilayah pertanian/padi (padi-sapi) merupakan upaya penurunan emisi gas metana dan memperbaiki siklus karbon dari subsektor peternakan (Agus et al., 2013).

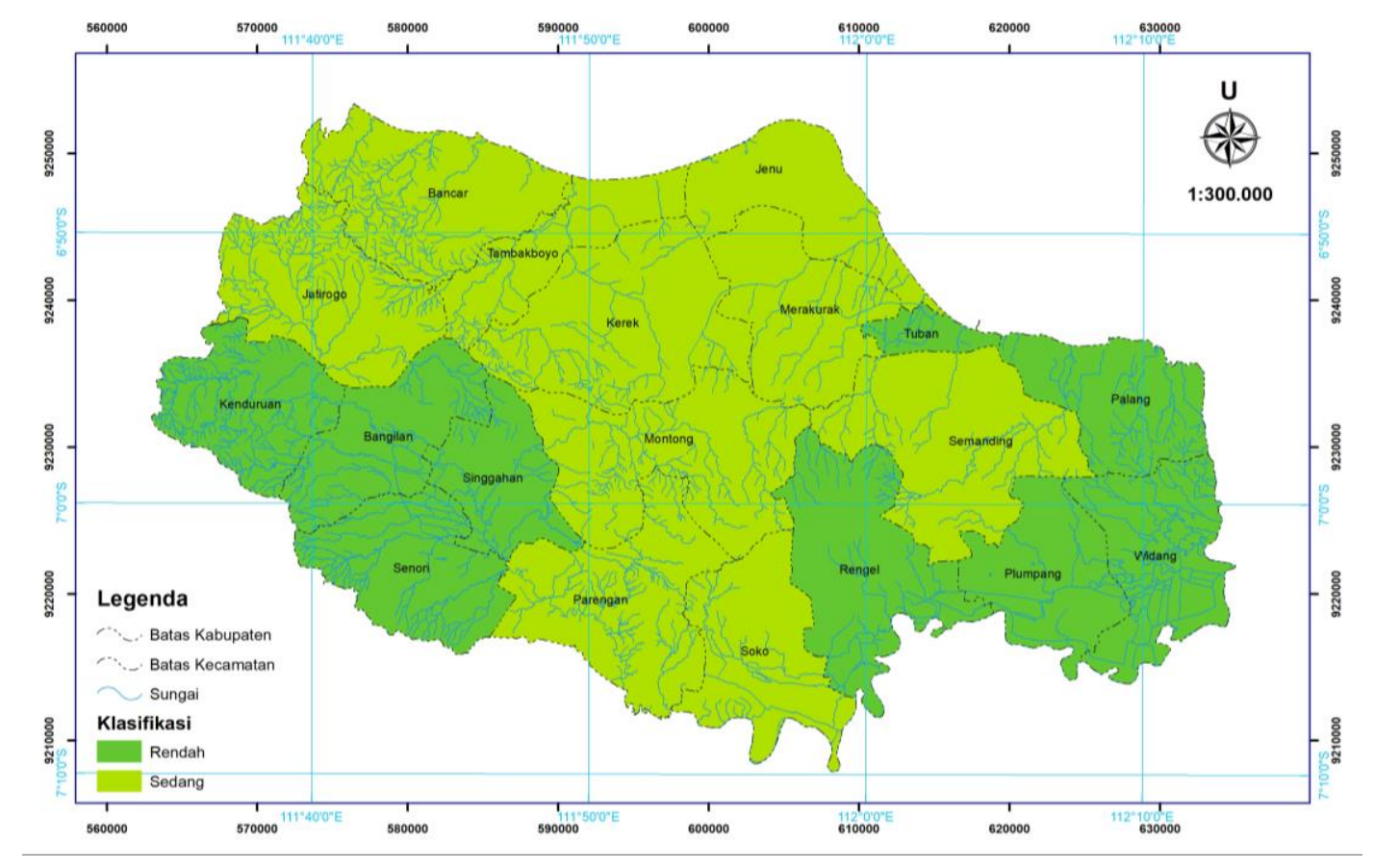

Gambar 4. Sebaran Emisi Gas Rumah Subsektor Peternakan di Kabupaten Tuban

\section{Potensi Aksi Mitigasi}

Terdapat beberapa opsi aksi mitigasi yang dikembangkan Badan Penelitian dan Pengembangan Pertanian oleh Kementerian Pertanian (Susilawati et al., 2020). Opsi mitigasi tersebut diantaranya adalah: (1) penurunan emisi $\mathrm{CH}_{4}$ dari lahan sawah; (2) mitigasi emisi $\mathrm{N}_{2} \mathrm{O}$ melalui pemupukan berimbang pada tanaman padi; (3) peningkatan cadangan karbon tanah melalui penggunaan pupuk organik sebagai dampak penggunaan UPPO (Unit Pengolah Pupuk Organik); (4) peningkatan cadangan karbon tanah melalui olah tanah konservasi dan pengelolaan bahan organik; (5) peningkatan cadangan karbon 
tanah melalui penggunaan biochar; (6) mitigasi emisi GRK melalui pertanian tanpa bakar; (7) mitigasi emisi $\mathrm{CH}_{4}$ enterik melalui perbaikan kualitas pakan ternak; (8) mitigasi emisi $\mathrm{CH}_{4}$ melalui pemanfaatan biogas kotoran ternak; dan (9) mitigasi emisi $\mathrm{CO}_{2}$ dengan menaikkan muka air tanah gambut.

Namun berdasarkan hasil wawancara dengan petani, opsi mitigasi yang paling besar kemungkinannya untuk diterima petani dan diterapkan adalah pemupukan berimbang pada tanaman padi, dan menanam varietas padi yang rendah emisi. Pemupukan berimbang atau menurunkan dosis penggunaan pupuk urea akan mengurangi Emisi $\mathrm{CO}_{2}$ dari penggunaan pupuk urea. Sedangkan mengganti varietas padi rendah emisi, dari IR 64 menjadi varietas Ciherang akan mengurangi emisi yang bersumber dari pengolahan sawah $\left(\mathrm{CH}_{4}\right)$. Varietas Ciherang terbukti mampu menurunkan emisi GRK dibandingkan varietas lainnya (Mulyadi \& Wihardjaka, 2014).

Pada tahun 2019, total emisi GRK di subsektor peternakan dan pertanian adalah sebesar 1.665,67 $\mathrm{Gg} \mathrm{CO}_{2}$-eq. Apabila petani bersedia menerapkan opsi mitigasi pemupukan berimbang pada tanaman padi, dan menanam varietas padi yang rendah emisi tersebut, maka total emisi GRK yang dapat dikurangi adalah sebesar 156,43 $\mathrm{Gg} \mathrm{CO}_{2}$-eq atau total emisi menjadi 936,06 $\mathrm{Gg} \mathrm{CO}_{2}$-eq di subsektor pertanian (Tabel 5).

Tabel 5. Perhitungan Emisi Setelah Aksi Mitigasi

\begin{tabular}{clrr}
\hline No & \multicolumn{1}{c}{ Sumber Emisi Subsektor Pertanian } & $\begin{array}{c}\text { Total Emisi } \\
\text { Baseline } \\
\text { (Gg CO2-eq) }\end{array}$ & $\begin{array}{c}\text { Total Emisi Setelah } \\
\text { Aksi Mitigasi } \\
\text { (Gg CO2-eq) }\end{array}$ \\
\hline 1 & Emisi $\mathrm{CH}_{4}$ dari Pengolahan Sawah & 675,17 & 527,24 \\
2 & Emisi $\mathrm{CO}_{2}$ dari penggunaan pupuk urea & 23,05 & 19,21 \\
3 & Emisi $\mathrm{N}_{2} \mathrm{O}$ langsung dari pengelolaan lahan sawah & 380,14 & 377,83 \\
4 & Emisi $\mathrm{N}_{2}$ O tidak langsung dari pengelolaan lahan & 14,14 & 11,79 \\
& sawah & & 936,06 \\
\hline Total & & $1.092,50$ & 9 \\
\hline
\end{tabular}

Dilihat dari nilai penurunan emisi dari pemupukan berimbang, tampak bahwa opsi mitigasi ini belum memberikan kontribusi yang signifikan (Gambar 5). Berbeda dengan opsi penggunaan varietas rendah emisi yang lebih tinggi berkontribusi terhadap penurunan emisi gas rumah kaca (Gambar 6). Pada penelitian ini, varietas padi rendah emisi yang disimulasikan dengan metode Tier-1 IPCC 2006 adalah Ciherang, menggantikan IR-64 yang umumnya ditanam oleh petani di Kabupaten Tuban. Hal ini sejalan dengan penelitian yang dilakukan oleh Balai Penelitian Lingkungan Pertanian (Balingtan) yang menemukan bahwa mengganti cara irigasi terus-menerus dengan irigasi berselang (intermittent) dapat menurunkan emisi $\mathrm{CH}_{4}$ sebesar $78 \%$ dan penggunaan varietas padi rendah emisi $\mathrm{CH}_{4}$ mampu menurunkan emisi $\mathrm{CH}_{4}$ hingga 66-10\% (Setyanto, 2015). Meskipun mengganti teknik irigasi mampu menekan emisi GRK dalam jumlah besar, namun petani belum mampu beralih dari kebiasaan penggenangan terus menerus selama budidaya padi sawah.

Petani mempertimbangkan penerapan aksi mitigasi berdasarkan biaya yang harus dikeluarkan, kemudahan dalam mengerjakan, dan peluang pendampingan dari pihak lain. Hal ini menyebabkan dipilihnya dua opsi mitigasi yaitu pemupukan berimbang pada tanaman padi, dan menanam varietas padi yang rendah emisi. Meski hanya memilih dua opsi mitigasi, namun mampu mengurangi luas zona dengan emisi tinggi (Gambar 7). Kecamatan Rengel yang awalnya termasuk dalam kategori tinggi dengan emisi 73,74 Gg $\mathrm{CO}_{2}$-eq menjadi sedang dengan jumlah emisi 68,88 $\mathrm{Gg} \mathrm{CO}_{2}$-eq. Begitu pula dengan Kecamatan Singgahan, Montong dan Parengan juga mengalami penurunan kelas emisi gas rumah kaca. 


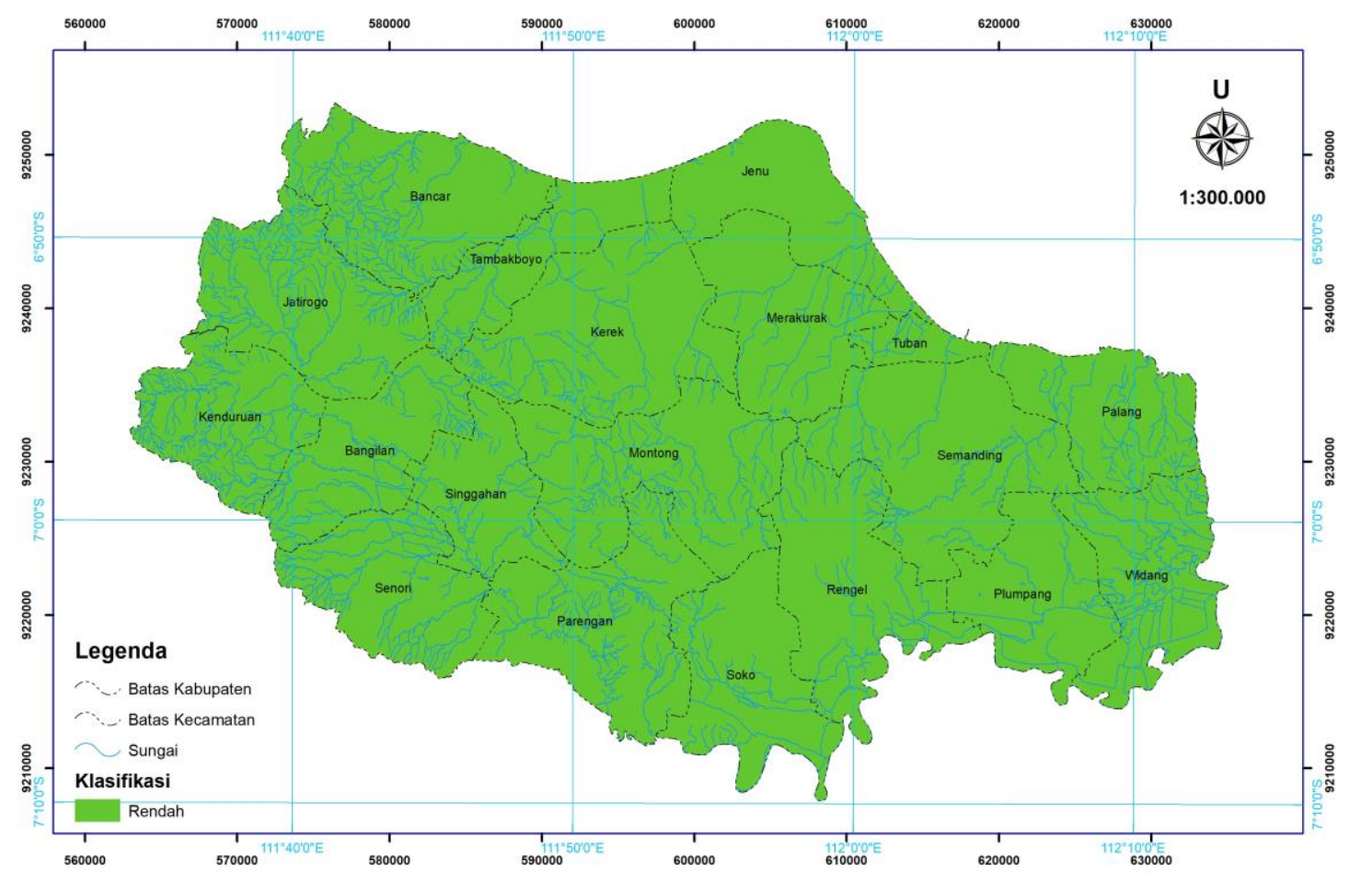

Gambar 5. Sebaran Kontribusi Penurunan Emisi dari Pemupukan Berimbang di Kabupaten Tuban

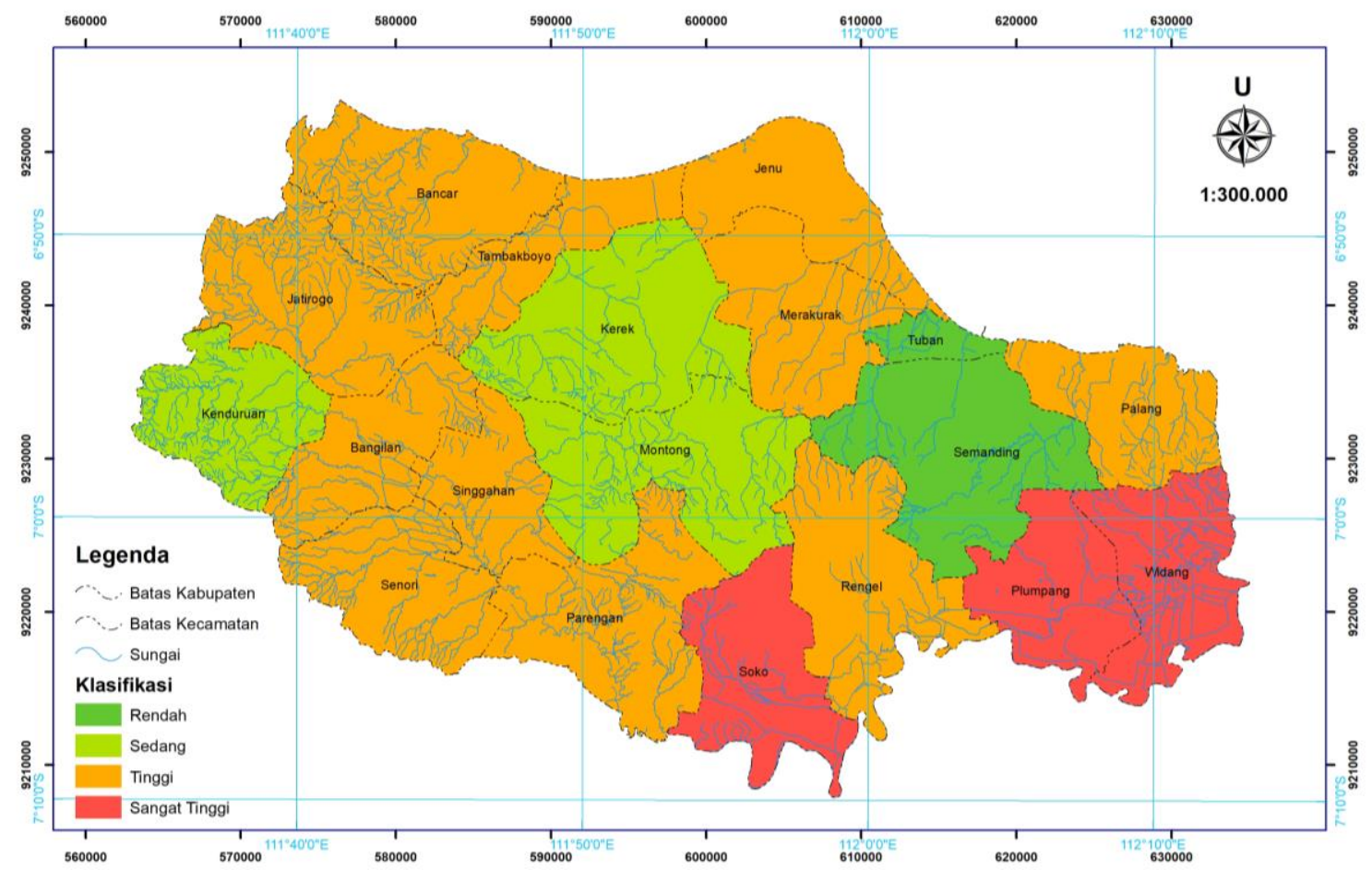

Gambar 6. Sebaran Kontribusi Penurunan Emisi dari Penggunaan Varietas Padi Rendah Emisi di Kabupaten Tuban 


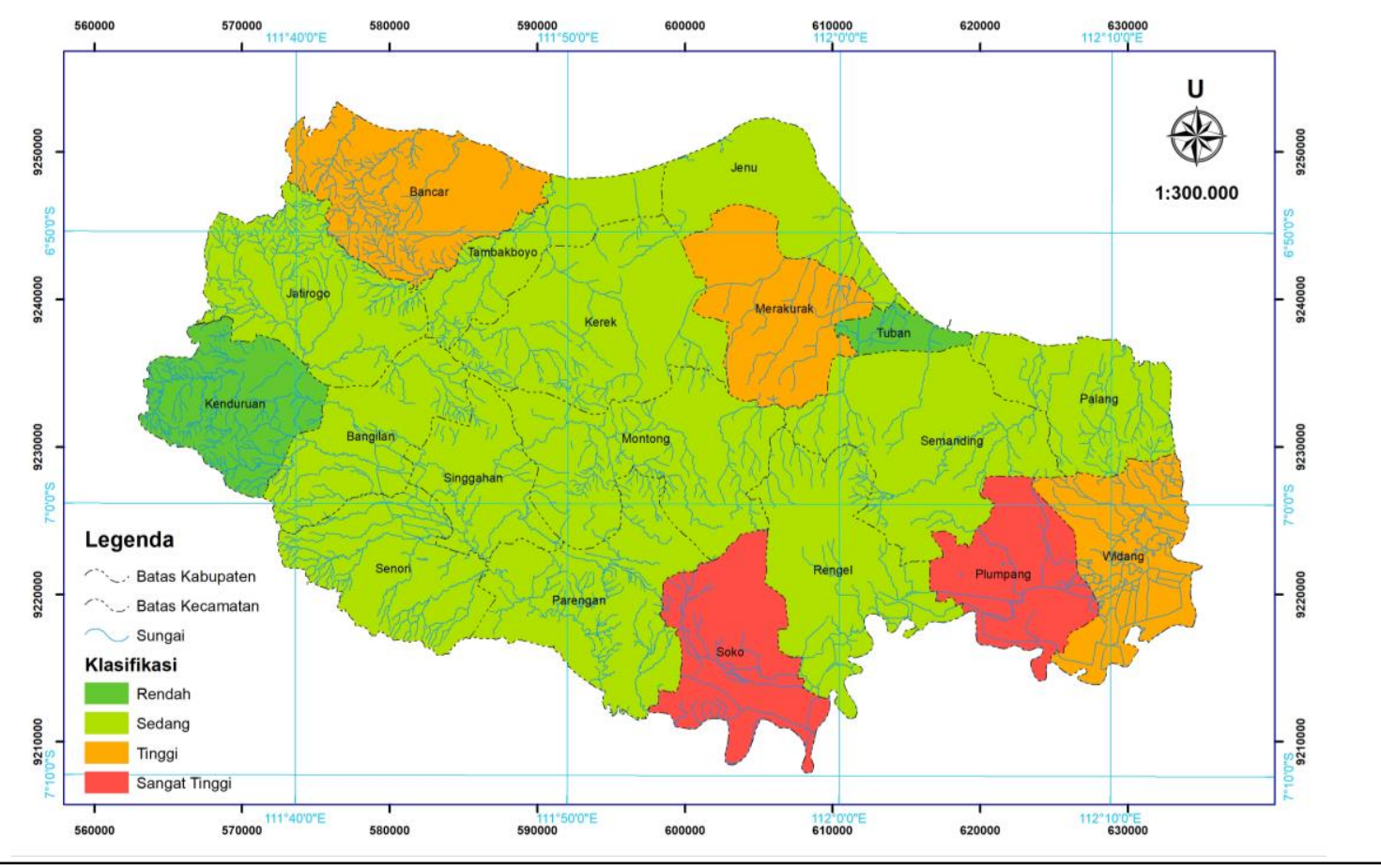

Gambar 7. Sebaran total emisi GRK setelah mitigasi di Kabupaten Tuban

Opsi mitigasi lainnya seperti penggunaan biochar, penambahan pupuk organik, penggunaan biogas dan perbaikan kualitas pakan ternak belum diprioritaskan oleh petani yang umumnya merangkap sebagai peternak. Hal ini dikarenakan opsi mitigasi tersebut membutuhkan biaya tambahan yang akan membebani operasional petani. Namun apabila ada pihak lain mendampingi dan mendukung pendanaan, petani siap menerima program mitigasi tersebut. Persepsi petani ini menjadi masukan berharga bagi pihak terkait di Kabupaten Tuban.

Selain opsi mitigasi di atas, terdapat satu opsi lainnya yang dapat dipertimbangkan oleh petani, yaitu penghematan air irigasi. Menghemat air irigasi mampu menurunkan emisi gas rumah kaca hingga 41\% (Pramono et al., 2018). Hasil penelitian lainnya juga membuktikan bahwa irigasi terputus mampu menekan emisi $\mathrm{CH}_{4}$ sampai $27 \%$ daripada irigasi terus menerus (Hervani \& Wiharjaka, 2014). Di Kecamatan Plumpang, Rengel dan Widang, irigasi sawah dikelola oleh organisasi petani bernama Himpunan Petani Pemakai Air (HIPPA). HIPPA hanya mengoperasikan pompa untuk menyalurkan air sungai Bengawan Solo menuju area persawahan. HIPPA hanya berorientasi pada luas sawah teririgasi tanpa mempertimbangkan jumlah air yang harus disalurkan. Apabila opsi mitigasi penghematan air irigasi akan diimplementasikan, maka HIPPA di Kabupaten Tuban harus dilibatkan.

Implementasi aksi mitigasi di sektor pertanian hanya dapat dilakukan dengan dukungan multipihak. Pemerintah didorong mengembangkan aksi mitigasi perubahan iklim dan bersinergi dengan akademisi, masyarakat, sektor swasta, dan media massa (Pentahelix). Pembangunan ekonomi masyarakat pedesaan sebagaimana diatur dalam Undang Undang Nomor 6 Tahun 2014 tentang Desa memungkinkan kolaborasi pentahelix guna memastikan keterlibatan semua pihak (Yunas, 2019). Hasil inventarisasi ini adalah kontribusi akademisi bagi Pemerintah Kabupaten Tuban dalam menyusun rencana aksi daerah penurunan emisi gas rumah kaca. Selain pemerintah sebagai leading sector, pihak swasta juga patut menunjukkan komitmennya. Tuban memiliki dua pabrik semen berskala nasional yang dalam proses produksinya menghasilkan emisi GRK yang sangat tinggi. Oleh 
karena itu, wajib bagi pabrik semen mempertimbangkan aksi mitigasi perubahan iklim sebagai bagian dari program Corporate Social Responsibility (CSR) perusahaan.

\section{Kesimpulan}

Emisi Gas Rumah Kaca sektor Pertanian di Kabupaten Tuban pada tahun 2019 mencapai 1.665,67 $\mathrm{Gg} \mathrm{CO}_{2}$-eq. Pada subsektor peternakan, Kecamatan Kerek menempati posisi teratas dalam berkontribusi terhadap emisi GRK dan terendah ada di Kecamatan Tuban. Sedangkan di subsektor pertanian, Kecamatan Plumpang menempati posisi teratas penyumbang emisi gas rumah kaca dan Kecamatan Tuban menempati posisi terendah. Petani hanya bersedia menerapkan aksi mitigasi berupa pemupukan berimbang dan penggunaan varietas padi rendah emisi karena keterbatasan biaya untuk penerapan aksi mitigasi lainnya. Melalui penerapan dua opsi mitigasi tersebut, beban emisi GRK di Kabupaten Tuban dapat dikurangi hingga 156,43 $\mathrm{Gg} \mathrm{CO}_{2}$-eq.

Hasil penelitian ini memberikan gambaran bahwa dalam menyusun sebuah aksi mitigasi perubahan iklim, keterlibatan masyarakat harus diutamakan tidak hanya berpedoman pada angka potensi penurunan emisinya. Penelitian ini juga mmberikan gambaran terkait pentingnya melakukan inventarisasi emisi GRK yang digunakan sebagai dasar dalam penyusunan rencana aksi daerah penurunan emisi GRK Kabupaten Tuban bersama-sama dengan Pemerintah Provinsi Jawa Timur. Penyusunan dokumen rencana aksi penurunan emisi GRK (RAD-GRK) sendiri merupakan amanat yang tertuang dalam Peraturan Presiden Nomor 61 Tahun 2011 tentang Rencana Aksi Daerah GRK (RAD-GRK).

Penelitan lanjutan perlu dilakukan untuk menghitung potensi penurunan emisi gas rumah kaca dari beberapa opsi mitigasi yang ada. Sehingga pilihan aksi mitigasi dapat menjadi bahan pertimbangan bagi semua pihak, tidak hanya petani atau masyarakat saja. Penelitian lanjutan juga perlu dilakukan untuk mengetahui tingkat pemahaman dan langkah-langkah operasional instansi terkait sehingga penyebarluasan informasi tentang perubahan iklim dapat terlaksana dengan baik.

\section{Daftar Pustaka}

Agus, F., Santosa, I., Dewi, S., Setyanto, P., Thamrin, Y., Wulan, C., \& Suryaningrum, F. (2013). Pedoman teknis perhitungan baseline emisi dan serapan gas rumah kaca sektor berbasis lahan: Buku I landasan ilmiah. Jakarta: Badan Perencanaan Pembangunan Nasional, Republik Indonesia.

Ariani, M., Setyanto, P., \& Ardiansyah, M. (2015). Biaya pengurangan marginal emisi gas rumah kaca sektor pertanian. Jurnal Agro Ekonomi, 33(2), 107-120. doi:10.21082/jae.v33n2.2015.107-120.

Arisandi, F. D., Setyanto, P., \& Ardiarini, N. R. (2018). Heritabilitas dan karakteristik tanaman padi rendah emisi gas metana. Jurnal Produksi Tanaman, 6(6), 1042-1047.

Badan Pusat Statistik (BPS) Provinsi Jawa Timur. (2020). Provinsi Jawa Timur dalam angka 2020. Badan Pusat Statistik.

Badan Pusat Statistik (BPS) Kabupaten Tuban. (2021). Kabupaten Tuban dalam angka 2020. Badan Pusat Statistik.

Goodland, R., \& Anhang, J. (2009). Livestock and climate change: What if the key actors in climate change are cows, pigs, and chicken? In World Watch (Issue December).

Haristyana, A., Suntoyo, \& Sambodho, K. (2012). Prediksi kenaikan muka air laut di pesisir Kabupaten Tuban akibat perubahan iklim. Jurnal Teknik ITS, 1(1), 161-165. doi:10.12962/j23373539.v1i1.1808.

Hervani, A., \& Wiharjaka, A. (2014). Efektivitas waktu pengambilan dan pengukuran contoh gas rumah kaca pada pengelolaan air di lahan sawah. Widyariset, 172), 227-232.

IPCC. (2006). 2006 IPCC guidelines for national greenhouse inventories - a primer. In H. S. Eggleston., K. Miwa., N. Srivastava., \& K. Tanabe (Ed.), Prepared by the National Greenhouse Gas Inventories 
Programme. Japan: IGES.

Johnson, J. M. F., Franzluebbers, A. J., Weyers, S. L., \& Reicosky, D. C. (2007). Agricultural opportunities to mitigate greenhouse gas emissions. Environmental Pollution, 150(1), 107-124. doi:10.1016/j.envpol.2007.06.030.

Kartikawati, R, \& Nursyamsi, D. (2013). Pengaruh pengairan, pemupukan, dan penghambat nitrifikasi terhadap emisi gas rumah kaca di lahan sawah tanah mineral Jurnal Ecolab, 72), 93-107. doi:10.20886/jklh.2013.7.2.93-107.

Kartikawati, R., Yulianingrum, H., Wihardjaka, A., \& Setyanto, P. (2018). Upaya adaptasi terhadap perubahan iklim pada lahan tadah hujan melalui budidaya padi rendah emisi metana. Prosiding Balai Besar Penelitian Tanaman Padi (BB Padi), November, 165-257.

Kementerian Lingkungan Hidup. (2012). Pedoman penyelenggaraan inventarisasi gas rumah kaca nasional. Jakarta: Kementerian Lingkungan Hidup.

Kementerian Pekerjaan Umum. (2010). Keputusan Menteri pekerjaan umum no 266/kpts/m/2010 tentang pola pengelolaan sumber daya air wilayah Sungai Bengawan Solo. Jakarta: Kementerian Pekerjaan Umum.

Lehne, J., \& Preston, F. (2018). Making concrete change: Innovation in low-carbon cement and concrete. Chatham House Report, 1-122.

Lintangrino, M. C., \& Boedisantoso, R. (2016). Inventarisasi emisi gas rumah kaca pada sektor pertanian dan peternakan di Kota Surabaya. Jurnal Teknik ITS, 5(2), 53-57. doi:10.12962/j23373539.v5i2.16528.

Mulyadi, M., \& Wihardjaka, A. (2014). Emisi gas rumah kaca dan hasil gabah dari tiga varietas padi pada lahan sawah tadah hujan bersurjan. Jurnal Penelitian Pertanian Tanaman Pangan, 33(2), 116-121. doi:10.21082/jpptp.v33n2.2014.p116-121.

Munawaroh, I. S., \& Widiawati, Y. (2017). Profil emisi gas rumah kaca dari sapi potong di 34 provinsi menggunakan metode tier-2. Prosiding Seminar Nasional Teknologi Peternakan dan Veteriner 2017, 280291. doi:10.14334/Pros.Semnas.TPV-2017-p.280-291.

Mutiara, F. R., \& Hadiyanto, H. (2013). Evaluasi Efisiensi panas dan emisi gas rumah kaca pada rotary kiln pabrik semen. Teknik, 34(1), 9-13.doi:10.14710/teknik.v34i1.4812.

Nurhayati, I., \& Widiawati, Y. (2017). Emisi gas rumah kaca dari peternakan di Pulau Jawa yang dihitung dengan metode tier-1 ipcc. Prosiding Seminar Nasional Teknologi Peternakan dan Veteriner 2017, 292300. doi:10.14334/Pros.Semnas.TPV-2017-p.292-300.

Pemerintah Kabupaten Tuban. (2016). Rencana pembangunan jangka menengah daerah (RPJMD) Kabupaten Tuban Tahun 2016-2021. Tuban.

Pramono, A. (2016). Potensi penurunan emisi gas rumah kaca pada pengelolaan kotoran hewan sapi melalui pemberian pakan tambahan. Jurnal Hutan Pulau-Pulau Kecil, 1(2), 111-116. doi:10.30598/jhppk.2016.1.2.111.

Pramono, A., Jumari, J., \& Adriany, T. A. (2018). Penghematan air dan penurunan emisi gas rumah kaca pada perlakuan alternate wetting and drying di lahan sawah. Jurnal Ecolab, 12(1), 20-31. doi:10.20886/jklh.2018.12.1.20-31.

Purnamasari, E., Sudarno, S., \& Hadiyanto, H. (2020). Inventarisasi emisi gas rumah kaca sektor pertanian di Kabupaten Boyolali. Prosiding Seminar Nasional Geotik 2019 (pp 384-391).

Puspitasari, R., Muladno, M., Atabany, A., \& Salundik. (2015). Produksi gas metana (ch4) dari feses sapi fh laktasi dengan pakan rumput gajah dan jerami padi. Jurnal Ilmu Produksi dan Teknologi Hasil Peternakan, 3(1), 40-45. doi:10.29244/3.1.40-45.

Rahayu, D. (2017). Volume kendaraan di perbatasan Tuban lancar. Retrieved from: https://bloktuban.com/2017/07/02/volume-kendaraan-di-perbatasan-tuban-lancar/.

Schils, R. L. M., Olesen, J. E., del Prado, A., \& Soussana, J. F. (2007). A review of farm level modelling approaches for mitigating greenhouse gas emissions from ruminant livestock systems. Livestock Science, 112(3), 240-251. doi:10.1016/j.livsci.2007.09.005

Setyanto, P., Rosenani, A. B., Makarim, A. K., Che Fauziah I., Bidin, A., \& Suharsih, S. (2002). Soil controlling factors of methane gas production from flooded rice fields in Pati District, Central Java. Indonesian Journal of Agricultural Science, 3(1), 1-11. doi:10.21082/ijas.v3n1.2002.p1-11.

Setyanto, P. (2015). Teknologi mengurangi emisi gas rumah kaca dari lahan sawah. Iptek Tanaman Pangan, 
3(2), 205-214.

Sudarma, I. M., \& As-syakur, A. R. (2018). Dampak perubahan iklim terhadap sektor pertanian di Provinsi Bali. SOCA: Jurnal Sosial - Ekonomi Pertanian dan Agribisnis, 12(1), 87-98. doi:10.24843/SOCA.2018.v12.i01.p07.

Surmaini, E., Runtunuwu, E., \& Las, I. (2011). Upaya sektor pertanian dalam menghadapi perubahan iklim. Jurnal Penelitian dan Pengembangan Pertanian, 30(1), 1-7. doi:10.21082/jp3.v30n1.2011.p1-7.

Susilawati, H. L., Hervani, A., Pramono, A., Santoso, A. A., Siregar, A. F., Al-Viandari, N., Dariah, A., Maswar, Ariani, R., Widiawati, Y., Zuratih, Shiddieqy, M. I., Herliatika, A., Sarah, Ariani, M., \& Agus, F. (2020). Metode perhitungan mitigasi emisi gas rumah kaca sektor pertanian. Jakarta: Badan Penelitian dan Pengembangan Pertanian Kementerian Pertanian.

Suwarsih, Joesidawati, M. I., \& Tribina, A. (2019). Dampak perubahan iklim terhadap produktivitas industri tambak udang berdasarkan persepsi petambak udang (studi kasus: Kabupaten Tuban). Prosiding Seminar Nasional Kelautan, 1(1), 60-68.

Utaminingsih, W., \& Hidayah, S. (2012). Mitigasi emisi gas rumah kaca melalui penerapan irigasi intermittent di lahan sawah beririgasi. Jurnal Irigasi, 72), 132-141. doi:10.31028/ji.v7.i2.132-141.

Wiangga, L. S. (2017). Pertumbuhan produksi semen gresik dikatrol $10 \%$. Retrieved from: https://ekonomi.bisnis.com/read/20170422/257/647295/pertumbuhan-produksi-semen-gresikdikatrol-10.

Yunas, N. S. (2019). Implementasi konsep penta helix dalam pengembangan potensi desa melalui model lumbung ekonomi desa di Provinsi Jawa Timur. Matra Pembaruan, 3(1), 37-46. doi:10.21787/mp.3.1.2019.37-46. 